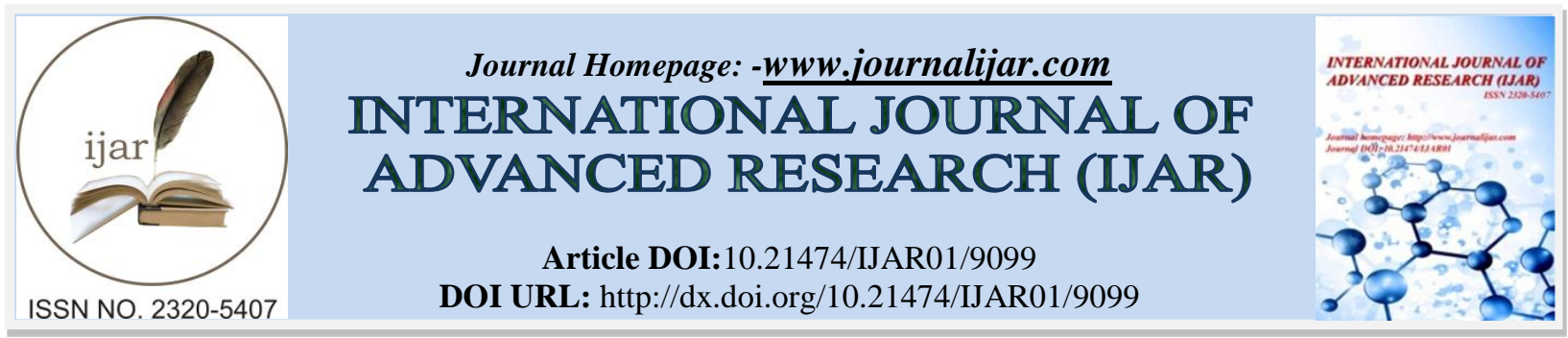

RESEARCH ARTICLE

\title{
A LITERARY REVIEW OF TWAKA SHARIR.
}

Dr.Awadhesh kumar, Dr. Bhoopal Shashidhar and Dr. Pankaj Kumar Rajvanshi.

1. Assistant Professor Department of Rachana Sharir, Major S. D. Singh PG Ayurvedic Medical College and Hospital, Fatehgarh- Farrukhabad, Uttar Pradesh.

2. Associate Professor department of Rachana Sharir, Himalayiya Ayurvedic PG medical college and Hospital Dehradun Uttarakhand.

3. Assistant Professor department of Rachana Sharir, Himalayiya Ayurvedic PG medical college and Hospital Dehradun Uttarakhand.

\section{Manuscript Info}

Manuscript History

Received: 20 March 2019

Final Accepted: 22 April 2019

Published: May 2019

Key words:-

Sharir, Twaka, Twaka vyadhi, Skin.

\section{Abstract}

Ayurveda is an ancient medical science which has given the concept of pancha gyanendriya among them twagindriya or sparshanendriya is the most important. The sparshanendriya is the sense organ which is meant for the sense of touch. It covers and protects the surface of the body from the heat, cold and external infections etc. human skin is a biological marvel. It is the protective covering of the body. Acharya Sushruta makes the knowledge of ayurveda more practical and useful. His great contribution to ayurvedic sharir include description and classification of various body structures like sira, dhamni, snayu, asthi, twaka etc.

Copy Right, IJAR, 2019,. All rights reserved.

\section{Introduction:-}

Twaka sharir is very elaborately explained in our classics. We can find description regarding layers of skin in Brihatrayi and laghutrayi. Acharya Sushruta has mentioned in the sharir sthana about the formation of twaka at the level of embryogenesis and has given the simily to the formation of cream on the milk. Ha has also described the thickness of each layer and several diseases which manifest in different layers of the twaka.

Human skin is a biological marvel. It is the protective covering of the body. It is having soft, pliable, strong, waterproof and self repairing properties. It is like a large container, without it all our delicate insides would spill right out.

Structurally integumentary system is most complex structure and highly specialized, hence it is grouped in the sense organ. This is most extensive organ system has the accessory structures, including hair, nails, glands and specialized nerve receptors for stimuli such as touch, cold, heat, pain and pressure.

The functions include protection of internal structures, prevention of entry of disease-causing microorganisms, temperature regulation, excretion through perspiration, pigmentary protection against ultraviolet sunrays and production of vitamin $\mathrm{D}$. The body stores about half of its fat in the underlying hypodermis.

\section{Corresponding Author:-Dr.Awadhesh kumar.}

Address:-Assistant Professor Department of Rachana Sharir, Major S. D. Singh PG Ayurvedic Medical College and Hospital, Fatehgarh- Farrukhabad, Uttar Pradesh. 


\section{Aim And Objective}

To make comprehensive study and compile the description about twaka sharir from different classical texts.

\section{Material And Method:-}

Various ayurvedic classics texts were used for this study as source materials. Main Ayurvedic books used are Brhitaryi and Laghutaryi etc. and available commentaries on it.

\section{Definition:}

In Sushruta Samhita, Acharya Sushruta has mentioned that when bhutatma adhisthita shukra and shonita get pakva it forms the seven layers of twaka and acharya has given the simily of this with ksheera santanika ${ }^{1}$. (Su.S. Sh. 4/4)

One among the indriyasthana, which completely covered by medas, shonita and all other dhatus of the body and spread all over the body. It is considered as the adhisthana of sparshanendriya as well as one of the main adhisthana of vata and also pitta dosha.

The skin is the largest organ of the body. As the primary interface between ourselves and our environment, the skin serves several distinct functions and it also the vehicle for the biological and social communication to the external world.

In ayurveda, the word twaka or charma is used for $\operatorname{skin}^{2}$.

Acharya Charaka described twaka as a matraja avayava which is one among the six bhavas essential for the development of fetus. ${ }^{3}$

\section{Samhita Kal}

Ayurveda was well developed at the time of samhita kal, it was known as golden era of ayurveda. This kal gives a great knowledge about twaka sharir and its related disease.

\section{Charaka samhita:}

Layers of The Twaka According To Acharya Charaka ${ }^{4}$ :

In the $7^{\text {th }}$ chapter of sharir sthana acharya Charaka has explained about the six layers of the skin and the diseases which occur in each layer, following layers are:

\section{Udakadhara:}

It is an outermost layer of twaka, as per the name it holds rasa dhatu and lasika inside the body and prevents their loss from the body.

\section{Asrugdhara:}

Second layer is asrugdhara which retains the rakta.

Third layer is the site for the manifestation of the Sidma and kilash disease.

Fourthlayer is the site for manifestation of the Dadru and Kushta.

Fifth layer is the site for Alaji and Vidradhi.

Six layer is the site in which any excision of the part can produce severe symptoms, and also it is the site for Arunshika on sthula parva which are rakta and Krishna varna, such are difficult to treat. This layer is the one on excision of which causes loss of consciousness.

\section{Sushruta samhita:}

Susruta Acharya has explained about skin very minutely, he has described embryological development of skin and its layers. He has described the pramana, characters of each layer of twaka and diseases. ${ }^{5}$

\section{Layers Of The Twaka According To Acharya Sushruta: ${ }^{6}$}

Acharya sushruta explained the twaka as the twaka is the produced by the union of shukra and shonita and the simily has been coated as the formation of cream after boiling the milk. 
Acharya Sushruta also mentioned the thickness of each layer as well as the diseases which will occur in respective layers.These seven layers of twaka are as following:

1. Avabhaasini: it is the firstand outermost layer which is express the colour and illuminates the five kinds of chaaya and it is having the thickness of $1 / 18^{\text {th }}$ part of vreehi and it is the region for the diseases like, sidma and padmakantaka.

2. Lohita: it is the second layer which is having the thickness of $1 / 16^{\text {th }}$ part of vreehi and it is the region for the disease like, tilkalaka, nyachha and vyanga.

3. Shweta: it is the third layer which is having the thickness of $1 / 12^{\text {th }}$ part of vreehi and it is the region for the disease like, charmadala, ajagallika and mashaka.

4. Taamra: it is the fourth layer which is having the thickness of $1 / 8^{\text {th }}$ part of vreehi and it is the region for the disease like, kilaasa and kusta.

5. Vedini: it is the fifth layer which is having the thickness of $1 / 5^{\text {th }}$ part of vreehi and it is the region for the disease like, kusta and visarpa.

6. Rohini: sixth layer is rohini, it is having the thickness is equal to the size of vreehi and it is the region for the disease like, granthi, apache, arbuda, slipada and galaganda.

7. Mamsadhara: the innermost and seventh layer is mamsadhara, it is having the thickness is double to the size of vreehi and it is the region for the disease like, bhagandara, vidhradi and arshas.

The thickness of the each layer is broadly applicable for the rich muscular parts and cannot be considered in the region of scalp or less fleshy areas.

Acharya Sushruta's measurement regarding thickness of the twaka is seems to be more accurate. His measurement of thickness of all the types of twaka expressed in modern units is very much similar to the thickness of skin given in modern text books of anatomy.

\section{Layers of the twaka according to astanga sangraha ${ }^{7}$ :}

1. Acharya Vagbhatta mentioned about the twaka first layer is Bhasini which is udakdhara, second layer is asragdhara, third layer is shweta which is the adhisthana of sidhma and kilasha, $4^{\text {th }}$ layer is tamra, $5^{\text {th }}$ layer is vedini which is the adhisthana of alaji and vidradhi, $6^{\text {th }}$ layer is rohini which is prandhara, is one on excision of which causes loss of consciousness, and adhisthana of arunshika and Krishna rakta which is dushchikitsya. $7^{\text {th }}$ layer is Mansadhara.

2. Acharya Vagbhata mentioned about the twaka pramana, the pramana of first layer is $1 / 18^{\text {th }}$ vreehi, $2^{\text {nd }}$ layer is $1 / 16^{\text {th }}$ vreehi, $3^{\text {rd }}$ layer is $1 / 12^{\text {th }}$ vreehi, $4^{\text {th }}$ layer is $1 / 8$ vreehi, $5^{\text {th }}$ layer is $1 / 5^{\text {th }}$ vreehi, $6^{\text {th }}$ layer is vreehi pramana, $7^{\text {th }}$ layer is two vreehi pramana.

\section{Layers of the twaka according to astanga hrudaya ${ }^{8,9}$ :}

1. Acharya Vagbhata in Astanga Hrudaya mentioned the embryological development of twaka in $3^{\text {rd }}$ chapter.

2. Acharya explains very briefly as the twaka is produced by the Asruja and same method has been coated as Acharya Sushruta.

3. In Sarvanga sundari teeka, Acharya Arundatta has explained about the seven twaka, these are Bhashini, Lohini, Shweta, Tamra, Twagvedini, Rohini and Mansadhara.

4. According to acharya Arundatta the pramana of Bhashini is $1 / 18^{\text {th }}$ vreehi, lohini is $1 / 16^{\text {th }}$ vreehi, sweta $1 / 12^{\text {th }}$ vreehi, Tamra is $1 / 8^{\text {th }}$ vreehi, twagvedini is $1 / 5^{\text {th }}$, Roini is vreehi pramana, mansadhara is two vreehi pramana.

5. Bhashini is havingfive kinds of chaaya,second layer Lohini is Asragdhara which retains the Rakta, sweta is the adhisthana of Sidhma and Shvitra, Tamra is the adhisthana of Sarva Kushta, Twagvedini is the adhisthana of Vidradhi and Alaji, , Roini layer is one on excision of which causes loss of consciousness. In seventh layer there is the adhisthana of Arunshika and Krishna rakta and it is duschikitsya.

\section{Relation between panchamahabhuta and twaka:}

1. Prathvi: Twaka has been considered as the upadhatu of mamsadhatu that shows it is stable.

2. Jala: Presence of jala makes the twaka snigdha and sthira.

3. Agni: Having specific varna and lusture because of agni.

4. Vayu: Adhistana of sparshanendriya.

5. Akasha: Sookshma srotas of sweda are the indicators. 
In the reference of gnanendriya ${ }^{10}$ :

Aacharya Charaka opines, indriya is the source of obtaining the knowledge and performing actions these are sookshma and are present in certain specific places of the body which are known as indriya adhistaana, these are karna, twaka, netra, jivha and nasa.

\section{Twaka in relation with dosha:}

Vata:

It is residing in the twaka and produces discoloration, twitching, roughness, pricking pain when it is vitiated. ${ }^{11}$

Pitta:

It is residing in the twaka known as Braajaka pitta and it is responsible for the digestation and absorption and also it helps in expression of vrna of the twaka and enables the digestation and utilization of substances used through abhyanga, parisheka, avagahana etc. it indicates the glow of one's natural complexion. ${ }^{12}$

\section{Pitta kshaya lakshana:}

When it decreases there will be reduction of body heat as well as pachakaagni and loss of complexion. ${ }^{13}$

Acharya charaka said that the production of normal and abnormal colour of the twaka is belongs to the pitta dosha. Chakrapani comments on the regulation of the body heat and variations in the colour of the twaka are the function of the Bhrajaka pitta.

Vagabhata acharya observes, Bhrajaka pitta is situated in the twaka, it imparts the lusture and radiance of the twaka.

Acharya Bhel explains that Bhrajaka pitta is responsible for the specific characteristics in the body like, it creats various prabha of head, hand feet etc.

Twaka and Kapha dosha: The snigdhatva, slekshnta, mruduta, sheetata, prasannata and snigdhvarna such qualities are derived from kapha dosha.

Twaka and dhatu:

Twaka And Rasa Dhatu:

At several places twaka has been used as a synonym of Rasa dhatu like twaksara purusha etc. in the context of kusta Acharya Sushruta has mentioned in early stages kusta is situated only in the twaka, Dalhana comments on it and says that twakaashrita i.e. Rasashrita kusta. ${ }^{14}$

\section{Twaka And Rakta Dhatu:}

Acharya sushruta mentioned the function of rakta dhatu as varna prasadana i.e. it imparts the colour of the twaka, mamsapusti i.e. nourishes the mamsadhtu in the body.

Twaka and mamsadhatu:

It is upadhatu of mamsadhatu.

\section{Relation Between Twaka And Mala:}

There will be blockage of lomakoopa and dryness of the skin altered perception in the skin. ${ }^{15}$

The Relation Of Twaka In The Other Diseases:

In the context chaya and prabha Acharya Charaka explains in indriyasthana as, the chaya surcumpscribes the complexion of the body where as prabha illuminates the complexion. ${ }^{16}$

In The Context Of Twaka Sara Lakshana:

Twaka will be snihgdha, shlekshna, alpagambheera, sukumarata, romayukta and prabhayukta. ${ }^{17}$

In The Context Of Poorvaroopa Of Kusta:

The roughness of the skin, itching sensation, excess or absence of sweat ${ }^{18}$. (Su.S. Ni. 5/4) 


\section{In The Context Of Vruna :}

Lesions in the skin can easily cured with compared to any other sites which are difficult to treat. Abnormal shapes of wound are also cured ${ }^{19}$. (Su. S. Su. 22/4)

In The Context Of Vidradhi:

Inflicted vatadi doshas first vitiate the twak, rakta, mansa and meda to produce the inflammation ${ }^{20}$. (Su. S. Ni.9/4)

In The Context Of Visarpa:

Infected doshas vitiated first twak (Lasika) and then rakta and mansa to produce the condition called visarpa ${ }^{21}$. (Su. S. Ni. 10/3)

\section{In The Context Of Pandu:}

There will be whitish yellow discoloration of twak and loss of sneha in the body.

In The Context Of Kamala:

There will be yellowish discoloration of the twak and netra ${ }^{22}$. (C. S. Chi. 16/35)

Factors for the formation of body complexion:

According to the Acharya Hareeta ${ }^{23}$ :

1. For Gaura Varna- Pitta

2. For Krishna Varna- Vata + Rakta

3. For Syama Varna- Vata+ Kapha, Rakta+Kapha

\section{Mahabhoota Pradhanyata In Varna:}

1. Gaura- teja + aap + akasha

2. Krishna- teja + prathvi + vayu

3. Syama- sarvabhoota

\section{Discussion:-}

1. The external covering of the body is called twaka. It is also called as "Twagindriya or spershanendriya" which is responsible for sense of touch or sparsha. It covers the surface of the body, holds the blood inside, illuminates the complexion and protects from the heat, cold and external infections etc.

2. Etymology of twacha is samvarane, meaning is covering of the body. Twacha, charma, chhavi, chhadini, sparsha and asrukdhara are the synonyms of the skin.

3. Acharya Charaka described six type of twaka namely udakadhara holds rasa dhatu and lasika inside and prevents loss from the body. Asrukdhara, which holds the numerous blood vessels.

4. Acharya Charaka mentioned in numbers like Trutiya, Chaturtha, Panchami and Shasti and narrated the Sidhma, Kilasa in trutiya, dadru in chaturtha, Alaji, Vidradhi inpanchami, hence loss of consciousness in exertion of shastidhara.

5. Acharya Vagbhata also same view of Charaka and also regarding vyadhis occurring in different layers.

6. Acharya Sushruta, Sharangadhara, Bhavapraksha have mentioned seven layers of twaka and same view regarding vyadhis occurring in different layers.

7. Acharya Charaka opines all the organs are made up of panchamahabhuta, naturally the Rachana and kriya of these organs have been organized according to their panchamabhutika constitution. Twaka has been counted in prathvi and vayu dominant organs. ${ }^{24}$

\section{Conclusion:-}

The following conclusions can be drawn by the observation based on literary review of the both ayurveda and modern.

1. Twaka is the most of the sensory organ of the body which covers surface and protects against heat, cold, infection etc.

2. In Ayurvedic classics all acharya's has given the explanation about the layers of twaka and their thickness with diseases which can be occur in this, these are given below. 
Table No 3:-Different Name Of Twaka According To Different Acharyas

\begin{tabular}{|l|l|l|l|l|l|}
\hline Sushruta & Charaka & $\begin{array}{l}\text { Astanga } \\
\text { Sangraha }\end{array}$ & $\begin{array}{l}\text { Astanga } \\
\text { Hrudaya }\end{array}$ & Sharangadhara & Bhela \\
\hline Avabhaasni & Udakadhara & Bhasini & Bhasini & Avabhaasini & Udakadhara \\
\hline Lohita & Asrukdhara & Asrukdhara & Lohini & Lohita & Asrukdhara \\
\hline Shweta & $3^{\text {rd }}$ & Shweta & Shweta & Shweta & $3^{\text {rd }}$ \\
\hline Tamra & $4^{\text {th }}$ & Tamra & Tamra & Tamra & $4^{\text {th }}$ \\
\hline Vedini & $5^{\text {th }}$ & Vedini & Twagvedini & Vedini & $5^{\text {th }}$ \\
\hline Rohini & $6^{\text {th }}$ & Rohini & Rohini & Rohini & $6^{\text {th }}$ \\
\hline Mamsadhara & - & Mamsadhra & Mamsadhra & Sthoola & - \\
\hline
\end{tabular}

Table No 4:-Vyadhi of Twaka According To Different Acharyas

\begin{tabular}{|c|c|c|c|c|c|}
\hline Sushruta & Charaka & $\begin{array}{l}\text { Astanga } \\
\text { Sangraha }\end{array}$ & $\begin{array}{l}\text { Astanga } \\
\text { Hrudaya }\end{array}$ & Sharangadhara & Bhela \\
\hline $\begin{array}{l}\text { Avabhaasni - } \\
\text { sidma and } \\
\text { padmakantaka }\end{array}$ & Udakadhara & Bhasini & Bhasini & $\begin{array}{l}\text { Avabhaasini- } \\
\text { sidhma }\end{array}$ & Udakadhara \\
\hline $\begin{array}{l}\text { Lohita- } \\
\text { Tilkalaka, } \\
\text { Nyachha and } \\
\text { Vyanga }\end{array}$ & Asrukdhara & Asrukdhara & Lohini- & Lohita- tilakalaka & Asrukdhara \\
\hline $\begin{array}{l}\text { Shweta- } \\
\text { charmadala, } \\
\text { Ajagallika and } \\
\text { Mashaka }\end{array}$ & $\begin{array}{l}\mathbf{3}^{\text {rd }}-\text { Sidma and } \\
\text { kilash }\end{array}$ & $\begin{array}{l}\text { Shweta- sidma } \\
\text { and kilasha }\end{array}$ & $\begin{array}{l}\text { Shweta- sidma } \\
\text { and Shvitra }\end{array}$ & $\begin{array}{l}\text { Shweta- } \\
\text { charmadala }\end{array}$ & $\begin{array}{l}\mathbf{3}^{\text {rd }}-\text { Sidma and } \\
\text { kilash }\end{array}$ \\
\hline $\begin{array}{l}\text { Tamra- kilaasa } \\
\text { and kusta }\end{array}$ & $\begin{array}{l}4^{\text {th }}-\text { Dadru and } \\
\text { Kushta }\end{array}$ & Tamra & $\begin{array}{l}\text { Tamra - Sarva } \\
\text { kushta }\end{array}$ & $\begin{array}{l}\text { Tamra - kilasa and } \\
\text { shvitra }\end{array}$ & $\begin{array}{l}4^{\text {th }} \text { - Dadru and } \\
\text { Kushta }\end{array}$ \\
\hline $\begin{array}{l}\text { Vedini- kusta and } \\
\text { visarpa }\end{array}$ & $\begin{array}{l}\mathbf{5}^{\text {th }} \text { - Alaji and } \\
\text { Vidradhi }\end{array}$ & $\begin{array}{l}\text { Vedini - Alaji } \\
\text { and Vidradhi }\end{array}$ & $\begin{array}{l}\text { Twagvedini- } \\
\text { Vidradhi and } \\
\text { Alaji }\end{array}$ & $\begin{array}{l}\text { Vedini - } \\
\text { sarvakushta }\end{array}$ & $\begin{array}{l}\mathbf{5}^{\text {th }} \text { - Alaji and } \\
\text { Vidradhi }\end{array}$ \\
\hline $\begin{array}{l}\text { Rohini- granthi, } \\
\text { apache, arbuda, } \\
\text { slipada and } \\
\text { galaganda }\end{array}$ & $6^{\text {th }}-$ Arunshika & $\begin{array}{l}\text { Rohini - } \\
\text { Arunshika }\end{array}$ & $\begin{array}{l}\text { Rohini- on } \\
\text { excision loss of } \\
\text { consciousness }\end{array}$ & $\begin{array}{l}\text { Rohini - granthi } \\
\text { and ganda }\end{array}$ & $6^{\text {th }}-$ Arunshika \\
\hline $\begin{array}{l}\text { Mamsadhara- } \\
\text { Bhagandara, } \\
\text { Vidhradi And } \\
\text { Arshas }\end{array}$ & - & Mamsadhra & $\begin{array}{l}\text { Mamsadhra- } \\
\text { Arunshika }\end{array}$ & Sthoola- vidradhi & - \\
\hline
\end{tabular}

\section{References:-}

1. Sushruta samhita yadavaji trikam ji acharya 7th ed. 2002, Varansi, Chaukhambha orientalia, Pp-824, P-355.

2. Agnivesha charaka samhita yadavji trikamaji acharya 5th ed. Varanasi, Chaukhambha Sanskrit samhita publisherPp-738, P 339.

3. Agnivesha charaka samhita yadavji trikamaji acharya 5th ed. Varanasi, Chaukhambha Sanskrit samhita publisherPp-738, P-310.

4. Charaka Samhita Pt Kashinath Shastry And Dr Gorakhanath Chaturvedi 22nd Edition, Varanasi, Chaukhambha Vishvabharti Publishers, Pp- 1024, P-910.

5. Maharshina Sushruten Virachita, Sushruta Samhita, Aayurvedatatwasandeepika, Hindivyakhya, Pratham Bhaga, Vykhyakar Kaviraj Dr. Ambikadattashastri, Chaumbha Sanskrut Sansthan, Varansi, Reprinted 2011, Pp 124, P-37

6. Sushruta samhita yadavaji trikam ji acharya 7th ed. 2002, Varansi, Chaukhambha orientalia, Pp-824, P-355.

7. Astanga sangraha, kaviraj atridev gupta 36th ed, varansi, krisnadas academy, P-300.

8. Shrimadvagbhattavirachitam, Ashtangahrudyam, Vidyotini Bhasha Teeka Vaktavya Parishishtasahitam, Kaviraj Atridev Gupta,Chaukhambha Prakashan,Shareer Sthana, 3rd Chapter, Sloka No.3, Reprint, Vi. S. 2069, Pp839, P- 250 
9. Astanga hrudaya, kaviraj atridev gupta 36th ed, varansi, krisnadas academy, Pp- 614, P-175.

10. Charaka samhita pt kashinath shastry and dr gorakhanath chaturvedi 22nd edition, varanasi, chaukhambha vishvabharti publishers, Pp- 1024, P-179.

11. Sushruta samhita, kaviraj ambikadutta shastry, 12th ed.,Varansi,Chakhumbha Sanskrit sansthan 2001, Pp$563, \mathrm{P}-230$.

12. Sushruta samhita, kaviraj ambikadutta shastry, 12th ed.,Varansi,Chakhumbha Sanskrit sansthan 2001, Pp$563, \mathrm{P}-89$.

13. Sushruta samhita, kaviraj ambikadutta shastry, 12th ed.,Varansi,Chakhumbha Sanskrit sansthan 2001, Pp$563, \mathrm{P}-58$

14. Sushruta samhita, kaviraj ambikadutta shastry, 12th ed.,Varansi,Chakhumbha Sanskrit sansthan 2001, Pp$563, \mathrm{P}-247$

15. Sushruta samhita, kaviraj ambikadutta shastry, 12th ed.,Varansi,Chakhumbha Sanskrit sansthan 2001, Pp$563, \mathrm{P}-247$

16. Charaka samhita pt kashinath shastry and dr gorakhanath chaturvedi 22nd edition, varanasi, chaukhambha vishvabharti publishers, Pp- 1024, P- 996.

17. Charaka samhita pt kashinath shastry and dr gorakhanath chaturvedi 22nd edition, varanasi, chaukhambha vishvabharti publishers, Pp- 1024, P775.

18. Sushruta samhita, kaviraj ambikadutta shastry, 12th ed.,Varansi,Chakhumbha Sanskrit sansthan 2001, Pp$563, \mathrm{P}-247$

19. Sushruta samhita yadavaji trikam ji acharya 7 th ed. 2002, Varansi, Chaukhambha orientalia, Pp-824, P-95.

20. Sushruta samhita yadavaji trikam ji acharya 7 th ed. 2002, Varansi, Chaukhambha orientalia, Pp-824, P-263.

21. Sushruta samhita yadavaji trikam ji acharya 7th ed. 2002, Varansi, Chaukhambha orientalia, Pp-824, P-267.

22. Charaka samhita pt kashinath shastry and dr gorakhanath chaturvedi 22nd edition, varanasi, chaukhambha vishvabharti publishers, Pp- 1024, P-492.

23. Harit samhita, text with 'Nirmala' Hindi commentary, editor and translator, Vaidya Jaymini Panday, 1st edition 2010, Varanasi, chaukhamba visvabharati, Pp-544, P-540.

24. Charaka samhita pt kashinath shastry and dr gorakhanath chaturvedi 22nd edition, varanasi, chaukhambha vishvabharti publishers, Pp- 1024, P-492. 